Research Paper

\title{
Assessing the Suitability of Sewage-Sludge Produced in Kolkata, India for Their Agricultural Use
}

\author{
S SAHA $^{1, *, \#, \text { B N SAHA }^{2}, \text { G C HAZRA }^{3}, \text { S PATI }^{1}, \text { B PAL }^{1} \text {, D KUNDU }}{ }^{1}$, A GHOSH BAG $^{1}$, N CHATTERJEE $^{1}$ \\ and K BATABYAL ${ }^{1}$ \\ ${ }^{1}$ Directorate of Research, Bidhan Chandra Krishi Viswavidyalaya, Kalyani, Nadia, West Bengal 741 \\ 235, India \\ ${ }^{2}$ Dr. Kalam Agricultural College, Bihar Agricultural University, Dist. Kishanganj, Bihar 855 107, India, \\ ${ }^{3}$ Department of Agricultural Chemistry and Soil Science, Bidhan Chandra Krishi Viswavidyalaya, \\ Mohanpur, Nadia, West Bengal 741 252, India
}

(Received on 05 January 2018; Revised on 21 March 2018; Accepted on 07 May 2018)

\begin{abstract}
In this study, the suitability of sludges produced in Kolkata, India for their agricultural usage has been assessed by analyzing the plant nutrients availability, heavy metals loads, and their mobility, in terms of the rate of release and potential negative effect on soil and plants by using sequential chemical extraction procedures. Results indicated that the sludge produced at different sewage treatment plants (STPs) of Kolkata were rich in organic C (9.75-15.88\%) and major nutrients mainly N (2.05-3.87\%) and P (1.62-2.47\%); but the K content (0.98-1.96\%) was much lower. The concentrations of $\mathrm{Zn}$ (1332.1-2584.6 mg kg-1), Pb (309.6-608.5 mg kg-1), Ni (125.5-388.5 mg kg-1), Cu (136.6-451.7 mg kg-1) (excepting Bhatpara and Chandannagar) and Cd (3.22-10.09 $\mathrm{mg} \mathrm{kg}^{-1}$ ) (excepting Kamarhati and Garden Reach) in sludges of all the sites exceeded permissible standards as recommended by the Central Pollution Control Board (CPCB), India and should be restricted for use in agriculture. Speciation study also revealed that a considerable portion of $\mathrm{Zn}, \mathrm{Cd}, \mathrm{Pb}$ and $\mathrm{Ni}$ were distributed in the exchangeable, $\mathrm{MnO}_{2}$ and sesquioxide bound fractions, indicating high bioavailability and potential toxicity to the environment, while $\mathrm{Cu}$ was primarily distributed in the organically bound fraction. This study therefore suggests that the sludges produced in Kolkata, should not be used directly in agricultural purposes unless subjected to bioremediation or chemical remediation for reducing heavy metals load to a permissible level.
\end{abstract}

Keywords: Bioavailability; Essential Nutrients; Environmental Contamination; Heavy Metals; Sewage-sludge

\section{Introduction}

India has been producing significant quantity of industrial and city wastes annually and their disposal has now become a serious problem due to rapid industrialization and urbanization during the last few decades. An estimated 38,354 million liters of sewage with an equivalent amount of sludge per day is presently generated in India (Kaur et al., 2012). Nutrient potential of available sewage in India is estimated to be more than 350,000 tonnes N, 150,000 tonnes $\mathrm{P}$ and 200,000 tonnes K per year (Juwarkaret al., 1991). Due to high economic and environmental costs of incineration and land filling operation, land application of sewage sludge may be a more preferred option, as it provides an opportunity to recycle the organic matter (OC), N, P, and other plant nutrients (Dubey et al., 2006; Liu and Sun, 2013) and waste water as supplemental irrigation to land (Menget al., 2016). Therefore, use of municipal sewage sludge in agriculture as an organic fertilizer proved beneficial for a variety of field crops (Outhmanet al., 2016; Saha et al., 2017), as well as different vegetables (Balkhair and Ashraf, 2016).

As sewage sludge is a very good source of

*Author for Correspondence: E-mail: sushanta.hau@gmail.com \#Present address of the author: Dept. of Agriculture, Govt. of West Bengal, Sandeshkhali-II block, North 24 Parganas, West Bengal 743 446, India 
organic matter, it often improves the soil's physical and chemical properties and enhances it'sbiological activities (Silva et al., 2016; Saha et al., 2017). Thus its application to soil enables recycling of some major nutrients viz., $\mathrm{N}$ and $\mathrm{P}$ which may partially substitute the need for costly commercial fertilizers (Placek et al., 2016). However, indiscriminate sewage sludge application can disturb the soil quality especially with conjoint entry of high amount of heavy metals such as $\mathrm{Cd}, \mathrm{Ni}$, and $\mathrm{Pb}$ which may accumulate in edible plant tissues and cause food chain contamination (Saha et al., 2015).

Total metal contents are not the best indicators of their bioavailability and do not determine the nature of bonds in which they occur (Hooda and Alloway, 1994). The long-term use of sludge can cause heavy metal accumulation in soils. Even after short-duration application of sludge, the levels of heavy metals in soils can increase considerably. Thus, it is possible to characterize the degree of their solubility, mobility and plant availability in the soil system only after taking into account,various chemical forms in which different elements exist. Suchfractionation procedure facilitates the determination of percentage of water-soluble, exchangeable and easily soluble forms of a metal element out of the total content in sludge. On the basis of information about its concentration in soil as well as plant tissues, it may be considered as either a potential source of the nutrient for plants, or a threat for both plants and the whole environment. The present study was undertaken to work out heavy metal speciation and plant nutrient mobility and availability in sewage sludge generated from different sewage treatment plants in Kolkata for their safe disposal and recycling for crop production.

\section{Materials and Methods}

\section{Sampling Site}

Sludge samples were collected from nine municipal sewage treatment plants (STPs) from various locations in and around Kolkata viz., Bhatpara, Titagarh, Kamarhati, Howrah, Srirampur, Kalyani, Cossipore, Garden Reachand Chandannagar during November, 2012 to February, 2013 (Fig. 1). Out of these nine treatment plants, Titagarh, Cossipore, Garden Reach followed activated sludge process (ASP), Kamarhati, Howrah, Srirampur followed trickling filter (TF) and Bhatpara followed oxidation pond (OP), whereas Kalyani and Chandannagar followed both TF and OP for unloading the pollutants (Table 1). The samples were not taken from the outer layer of the heap as the material was very dry in those places. Six to ten representative samples were taken from one heap using an auger, they were mixed together to have a composite sample which was brought to laboratory for analysis. Triplicate samples were taken from each of the site for analysis in the laboratory.

\section{Chemical Analysis}

The sludge samples were air-dried, powdered and passed through $2.0 \mathrm{~mm}$ sieve for analysis of the $\mathrm{pH}$ (Page et al., 1982), EC (Richard, 1954), oxidizable organic carbon content (Walkley and Black method as modified by Nelson and Sommers, 1982). Total P, $\mathrm{K}$ and heavy metals $(\mathrm{Zn}, \mathrm{Cu}, \mathrm{Pb}, \mathrm{Cd}$, and $\mathrm{Ni}$ ) contents in the sludge were estimated by digesting representative samples $(1 \mathrm{~g})$ with di-acid mixture

Table 1: List of the STPs monitored

\begin{tabular}{llll}
\hline Name of STPs & \multicolumn{2}{c}{ Location } & \multicolumn{2}{c}{ Type of unit/treatment process } \\
\cline { 2 - 4 } & Latitude & Longitude & \\
\hline Bhatpara & $22^{\circ} 51.014^{\prime} \mathrm{N}$ & $88^{\circ} 23.863^{\prime} \mathrm{E}$ & Oxidation Pond \\
Titagarh & $22^{\circ} 44.022^{\prime} \mathrm{N}$ & $88^{\circ} 21.822^{\prime} \mathrm{E}$ & Activated Sludge Process \\
Kamarhati & $22^{\circ} 38.899^{\prime} \mathrm{N}$ & $88^{\circ} 23.649^{\prime} \mathrm{E}$ & Trickling Filter \\
Howrah & $22^{\circ} 59.195^{\prime} \mathrm{N}$ & $88^{\circ} 24.059^{\prime} \mathrm{E}$ & Trickling Filter \\
Srirampur & $22^{\circ} 43.944^{\prime} \mathrm{N}$ & $88^{\circ} 22.738^{\prime} \mathrm{E}$ & Trickling Filter \\
Kalyani & $22^{\circ} 58.465^{\prime} \mathrm{N}$ & $88^{\circ} 25.217^{\prime} \mathrm{E}$ & Trickling Filter and Oxidation Pond \\
Cossipore & $22^{\circ} 29.731^{\prime} \mathrm{N}$ & $88^{\circ} 23.494^{\prime} \mathrm{E}$ & Activated Sludge Process \\
Chandannagar & $22^{\circ} 51.757^{\prime} \mathrm{N}$ & $88^{\circ} 20.973^{\prime} \mathrm{E}$ & Trickling Filter and Oxidation Pond \\
Garden Reach & $22^{\circ} 31.340^{\prime} \mathrm{N}$ & $88^{\circ} 17.097^{\prime} \mathrm{E}$ & Activated Sludge Process \\
\hline
\end{tabular}




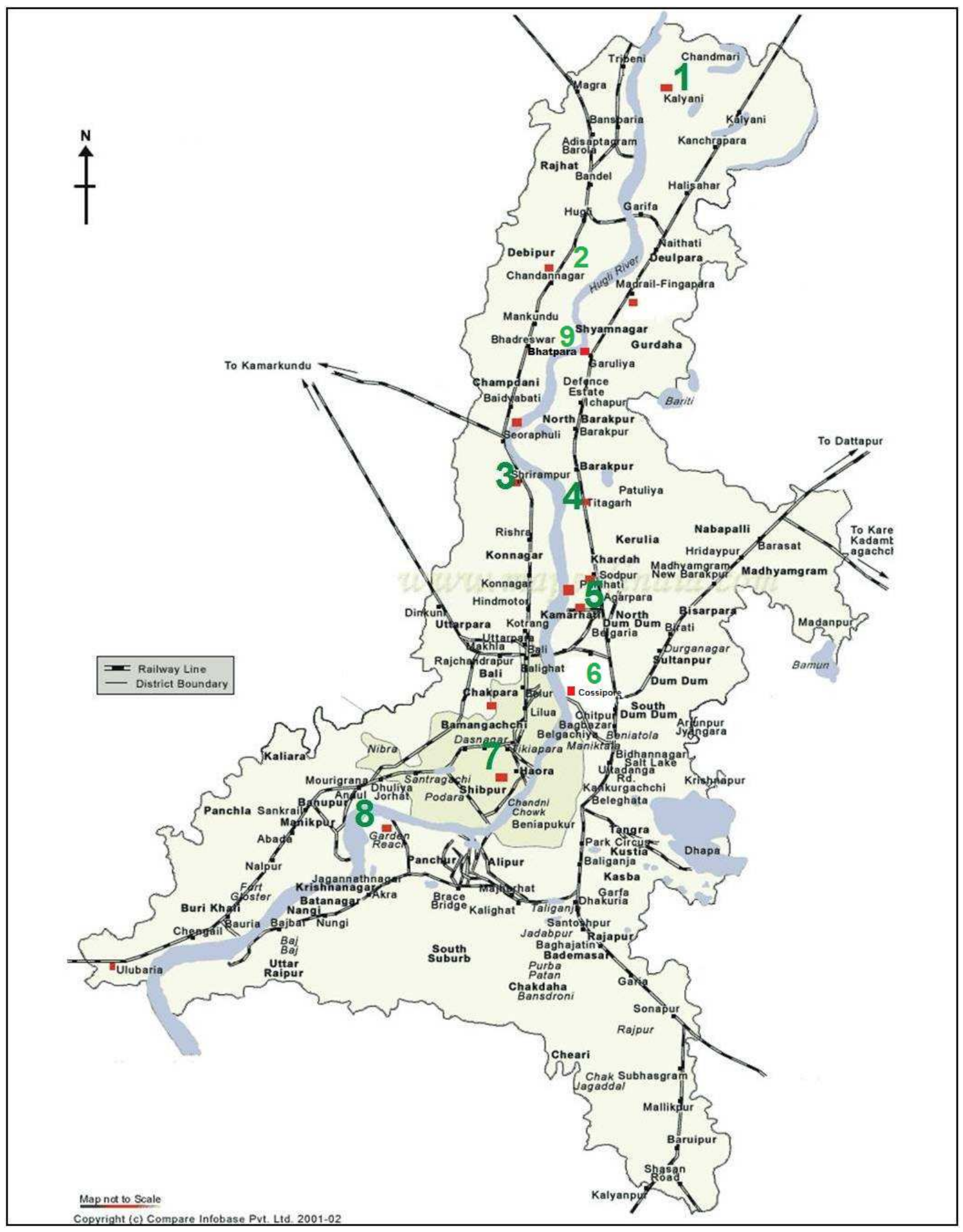

Fig. 1: Map showing the different locations of the sewage treatment plants (STPs) monitored

$\left(\mathrm{HNO}_{3}: \mathrm{HClO}_{4}:: 9: 4\right)$ at $80^{\circ} \mathrm{C}$ to obtain a clear solution (APHA, 1985). After digestion, the solutions were then filtered through Whatman no. 42 filter paper, and the filtrates were diluted to $50 \mathrm{~mL}$ with deionized water for further analysis. Total $\mathrm{N}$ content of the sludge samples were analyzed by Kjeldahl method using Kel- 
Plus analyzer (Pelican Equipments, Chennai, India), while total $\mathrm{P}$ and $\mathrm{K}$ content of the sludge samples were analyzed in aqueous extracts prepared after wetdigestion using UV-Visible spectrophotometer (Perkin Elmer, Lambda 65) and Flame photometer (Systronics 128), respectively (Jackson, 1973). Total heavy metal contents $(\mathrm{Zn}, \mathrm{Cu}, \mathrm{Pb}, \mathrm{Cd}$, and $\mathrm{Ni}$ ) of sludge samples in the aqueous extracts were then estimated by directly using atomic absorption spectrometer (GBC-902, Australia) (APHA, 1985).

\section{Heavy Metals Speciation}

The chemical partitioning of heavy metals in sludge sample was performed through sequential extraction process as suggested by Tessier et al. (1979), taking a duplicate sample ( $5 \mathrm{~g}$, oven-dried-wt. basis) in 50 $\mathrm{mL}$ polycarbonate centrifuge tube to obtain the following six operationally defined fractions. The scheme consisted of sequential extractions in the following order and operationally defined geochemical forms, as given in the Flow Chart. 1. Metal concentrations were determined using atomic absorption spectrometry (AAS) (GBC-902, Australia).

\section{Results}

Physico-chemical Characteristics and Nutrient

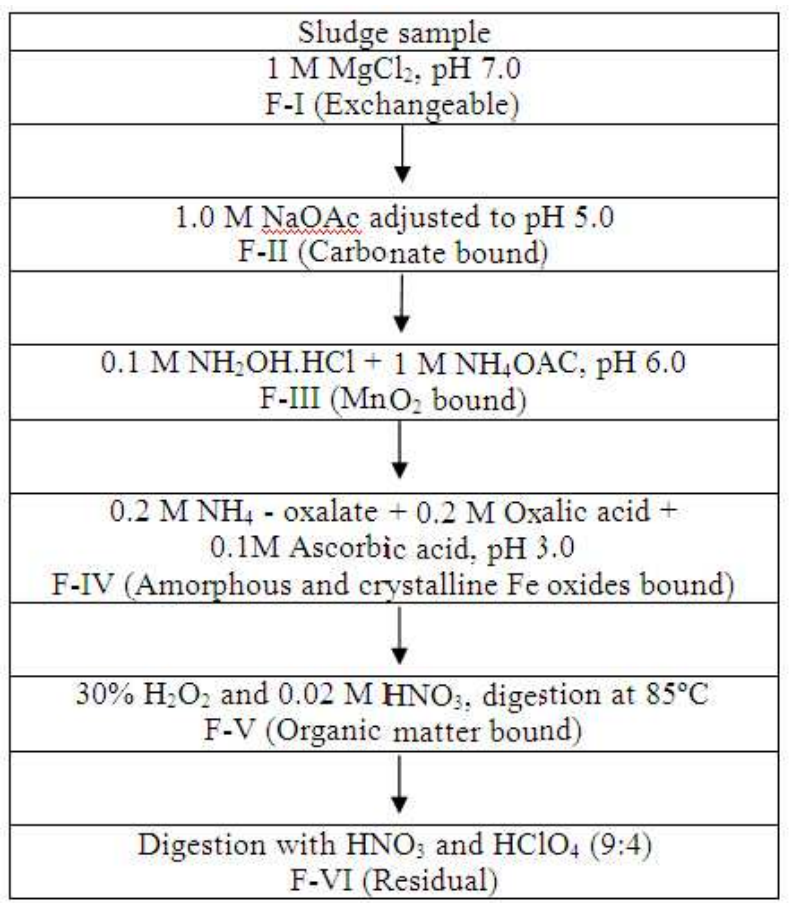

Flow Chart 1. Sequential extraction of different forms of heavy metal

\section{Status of Sludge}

The $\mathrm{pH}$ of sludge samples collected from nine STPs varied from 5.97-7.14 with a mean of 6.60 (Table 1). Organic carbon content was in the range of 9.75$15.88 \%$ with an overall mean of $12.68 \%$. The highest OC (\%) content was found in the sludge produced at Kamarhati (15.88), followed by Kalyani (14.75\%) and Bhatpara (13.98\%), whereas lowest at Howrah (9.75). Total N, P and K content was varied from 2.05-3.87, 1.62-2.47 and 0.98-1.96 with a corresponding mean of $3.02,2.06$ and $1.59 \%$ (Table 2).

On an average, the highest total $\mathrm{N}$ content was found in sludge originated from Titagarh $(3.87 \%)$ followed by Kalyani (3.61\%), Bhatpara (3.44\%) and Chandannagar $(3.41 \%)$, whereas sludge originated at Kalyani and at Srirampur were highest in total $\mathrm{P}$ $(2.47 \%)$ and total K $(1.96 \%)$ content, respectively (Table 2).

\section{Heavy Metals Concentration}

Total contents of different heavy metals viz., $\mathrm{Zn}, \mathrm{Cu}$, $\mathrm{Pb}, \mathrm{Cd}$ and $\mathrm{Ni}\left(\mathrm{mg} \mathrm{kg}^{-1} \mathrm{dw}\right)$ in sewage sludge at different locations of Kolkata and control standards for metals in sludges for agriculture use in India and some other countries $\left(\mathrm{mg} \mathrm{kg}^{-1}\right.$ dry matter) are represented in Table 3. The concentration of $\mathrm{Zn}, \mathrm{Cu}$, $\mathrm{Pb}, \mathrm{Cd}$ and $\mathrm{Ni}$ in sludge samples from different locations ranged from 1332.1-2584.6, 136.6-451.7, $309.6-608.5,3.22-10.09$ and $125.5-388.5 \mathrm{mg} \mathrm{kg}^{-1}$ dry weight, respectively, with a mean of $1812.48,324.99$, $470.76,5.69$ and $225.25 \mathrm{mg} \mathrm{kg}^{-1}$ dry weight of sludge, respectively. Irrespective of the sites, among different metals under consideration, $\mathrm{Cd}$ concentration in the sludge samples were lowest, while relatively lower concentrations of $\mathrm{Ni}, \mathrm{Cu}$ and $\mathrm{Pb}$ were found, but the content of $\mathrm{Zn}$ was relatively higher and it was maximum (2584.60 $\left.\mathrm{mg} \mathrm{kg}^{-1}\right)$ at Titagarh; sludge from Howrah showed highest content in total $\mathrm{Cu}$ (451.70 $\left.\mathrm{mg} \mathrm{kg}{ }^{-1}\right)$ and $\mathrm{Pb}\left(608.54 \mathrm{mg} \mathrm{kg}^{-1}\right)$. However, total $\mathrm{Cd}\left(10.09 \mathrm{mg} \mathrm{kg}^{-1}\right)$ and $\mathrm{Ni}\left(388.5 \mathrm{mg} \mathrm{kg}^{-1}\right)$ were found maximum in sludge samples from Srirampur and Kalyani locations, respectively.

Results also revealed that the content of different heavy metals also varied widely among the sites viz., Zn was relatively higher in Bhatpara, Titagarh and Graden Reach, $\mathrm{Cu}$ in Howrah and Graden Reach, $\mathrm{Pb}$ in Titagarh, Howrah and Srirampur, $\mathrm{Cd}$ in all the 
Table 2: Physico-chemical properties and major plant nutrient content of sludge

\begin{tabular}{|c|c|c|c|c|c|c|}
\hline Location & $\mathrm{pH}$ & $\begin{array}{c}\text { Organic C } \\
\%\end{array}$ & $\begin{array}{c}\text { Total C } \\
\%\end{array}$ & $\begin{array}{c}\text { Total-N } \\
\%\end{array}$ & $\begin{array}{c}\text { Total-P } \\
\%\end{array}$ & $\begin{array}{c}\text { Total-K } \\
\%\end{array}$ \\
\hline S1-Bhatpara & $6.58^{\mathrm{bc}}$ & $13.98^{b c}$ & $22.28^{\mathrm{ab}}$ & $3.44^{\mathrm{b}}$ & $1.99^{\mathrm{b}}$ & $1.56^{\mathrm{c}}$ \\
\hline S2-Titagarh & $6.33^{\mathrm{dc}}$ & $13.56^{\mathrm{c}}$ & $19.98^{\mathrm{c}}$ & $3.87^{\mathrm{a}}$ & $1.85^{\mathrm{b}}$ & $0.98^{\mathrm{e}}$ \\
\hline S3-Kamarhati & $6.87^{\mathrm{ab}}$ & $15.88^{\mathrm{a}}$ & $22.80^{\mathrm{a}}$ & $2.81^{\mathrm{c}}$ & $1.98^{\mathrm{b}}$ & $1.88^{\mathrm{ab}}$ \\
\hline S4-Howrah & $7.08^{\mathrm{a}}$ & $9.75^{\mathrm{f}}$ & $17.80^{\text {de }}$ & $2.05^{\mathrm{d}}$ & $2.43^{\mathrm{a}}$ & $1.81^{\mathrm{b}}$ \\
\hline S5-Srerampore & $6.49^{\mathrm{bc}}$ & $12.50^{\mathrm{d}}$ & $20.60^{\mathrm{c}}$ & $2.93^{\mathrm{c}}$ & $1.62^{\mathrm{c}}$ & $1.96^{\mathrm{a}}$ \\
\hline S6-Kalyani & $5.97^{\mathrm{d}}$ & $14.75^{\mathrm{b}}$ & $20.78^{b c}$ & $3.61^{\mathrm{b}}$ & $2.47^{\mathrm{a}}$ & $1.48^{\mathrm{c}}$ \\
\hline S7-Cossipore & $6.34^{\mathrm{dc}}$ & $10.28^{\mathrm{f}}$ & $16.90^{\mathrm{e}}$ & $2.85^{\mathrm{c}}$ & $1.85^{\mathrm{b}}$ & $1.85^{\mathrm{ab}}$ \\
\hline S8-Garden Reach & $7.14^{\mathrm{a}}$ & $11.40^{\mathrm{e}}$ & $20.98^{b c}$ & $2.21^{\mathrm{d}}$ & $1.98^{\mathrm{b}}$ & $1.23^{\mathrm{d}}$ \\
\hline S9-Chandannagar & $6.57^{\mathrm{bc}}$ & $12.00^{\mathrm{de}}$ & $18.52^{\mathrm{d}}$ & $3.41^{\mathrm{b}}$ & $2.40^{\mathrm{a}}$ & $1.54^{\mathrm{c}}$ \\
\hline Mean & 6.60 & 12.68 & 20.07 & 3.02 & 2.06 & 1.59 \\
\hline Std. dev. & 0.38 & 2.05 & 1.99 & 0.62 & 0.30 & 0.33 \\
\hline Range & $5.97-7.14$ & $9.75-15.88$ & $16.90-22.80$ & 2.05-3.87 & $1.62-2.47$ & 0.98-1.96 \\
\hline
\end{tabular}

*Values followed by different letters are significantly different at $P=0.05$ by Duncan's multiple-range test (DMRT)

Table 3: Total heavy metal contents of sewage sludge at different locations $\left(\mathrm{mg} \mathrm{kg}^{-1} \mathrm{dw}\right)$ and control standards for metals in sludges for agriculture use in India and some other countries $\left(\mathrm{mg} \mathrm{kg}^{-1} \mathrm{dw}\right)$

\begin{tabular}{|c|c|c|c|c|c|}
\hline Location & $\mathrm{Zn}$ & $\mathrm{Cu}$ & $\mathrm{Pb}$ & $\mathrm{Cd}$ & $\mathrm{Ni}$ \\
\hline S1-Bhatpara & $2521.50^{\mathrm{a}}$ & $136.60^{\mathrm{g}}$ & $388.80^{\mathrm{e}}$ & $5.96^{\mathrm{cd}}$ & $125.50^{\mathrm{f}}$ \\
\hline S2-Titagarh & $2584.60^{\mathrm{a}}$ & $327.22^{\mathrm{d}}$ & $572.50^{\mathrm{b}}$ & $5.66^{\mathrm{de}}$ & $129.10^{\mathrm{f}}$ \\
\hline S3-Kamarhati & $1511.20^{\mathrm{d}}$ & $342.22^{\mathrm{cd}}$ & $445.26^{\mathrm{d}}$ & $3.22^{\mathrm{g}}$ & $215.13^{\mathrm{d}}$ \\
\hline S4-Howrah & $1621.60^{\mathrm{cd}}$ & $451.70^{\mathrm{a}}$ & $608.54^{\mathrm{a}}$ & $6.80^{\mathrm{b}}$ & $224.75^{\mathrm{cd}}$ \\
\hline S5-Srerampore & $1514.30^{\mathrm{d}}$ & $352.80^{\mathrm{c}}$ & $553.50^{\mathrm{b}}$ & $10.09^{\mathrm{a}}$ & $198.50^{\mathrm{e}}$ \\
\hline S6-Kalyani & $1332.10^{\mathrm{e}}$ & $261.11^{f}$ & $309.60^{f}$ & $4.68^{\mathrm{f}}$ & $388.50^{\mathrm{a}}$ \\
\hline S7-Cossipore & $1658.80^{\mathrm{c}}$ & $375.80^{\mathrm{b}}$ & $428.89^{d}$ & $6.23^{\mathrm{c}}$ & $235.56^{\mathrm{c}}$ \\
\hline S8-Garden Reach & $2021.35^{\mathrm{b}}$ & $388.62^{b}$ & $426.98^{d}$ & $3.28^{\mathrm{g}}$ & $321.58^{b}$ \\
\hline S9-Chandannagar & $1546.84^{\mathrm{cd}}$ & $288.80^{\mathrm{e}}$ & $502.80^{\mathrm{c}}$ & $5.28^{\mathrm{e}}$ & $188.59^{\mathrm{e}}$ \\
\hline Mean & 1812.48 & 324.99 & 470.76 & 5.69 & 225.25 \\
\hline Std. dev. & 458.74 & 89.89 & 96.32 & 2.06 & 84.70 \\
\hline Range & $1332.1-2584.6$ & $136.6-451.7$ & $309.6-608.5$ & $3.22-10.09$ & $125.5-388.5$ \\
\hline $\mathrm{p}$ India & 1000.0 & 300.0 & 100.0 & 5.0 & 50.0 \\
\hline${ }^{\mathrm{q}}$ China & 1270.0 & 533.0 & 115.0 & 7.18 & 79.1 \\
\hline${ }^{\mathrm{r}} \mathrm{USA}$ & 2800.0 & 1500.0 & 300.0 & 10.0 & 420.0 \\
\hline${ }^{\mathrm{r}}$ Canada & 2000.0 & 500.0 & 200.0 & 10.0 & 100.0 \\
\hline${ }^{\mathrm{s} E u r o p e a n}$ Communities $(\mathrm{pH}<7.0)$ & 2500.0 & 1000.0 & 750.0 & 20.0 & 300.0 \\
\hline
\end{tabular}

*Values followed by different letters are significantly different at $P=0.05$ by Duncan's multiple-range test (DMRT)

${ }^{\mathrm{p} C P C B}$ (2005-06) for use of Municipal Solid Waste in Agriculture; ${ }^{\mathrm{q}}$ According to Ma et al. (2011); ${ }^{\mathrm{r}}$ According to Fuentes et al. (2004);

${ }^{\mathrm{s}}$ From the threshold values of heavy metals established in Directive 86/278/EEC as function of soil pH (Farmer, 2012) 
sites except Kamarhati, Kalyani, Graden Reach and Chandannagar and Ni in Kamarhati, Howrah, Srirampur, Kalyani and Graden Reach. A comparison of total metal contents in sludge with the maximum permissible standards as recommended by Central Pollution Control Board, India (CPCB, 2006) for use of municipal solid waste in agriculture (as no such regulation is available till date for direct use of sewagesludge in agriculture) indicated that the concentrations of $\mathrm{Zn}, \mathrm{Pb}$ and $\mathrm{Ni}$ in all the sludge sites exceeded the permissible levels and thus it should be restricted for agricultural use only. However, the concentrations of $\mathrm{Cu}$ in all locations excepting Bhatparaand Chandannagarand that of $\mathrm{Cd}$ excepting Kamarhati and Garden Reachexceeded permissible levels.

\section{Heavy Metals Speciation}

The degree of solubility or bioavailability of heavy metals does not depend on their total content in the sludge, but rather it depends on their speciation or the different chemical forms in which a metal persists in sludge. Heavy metals distributed in the exchangeable or soluble fraction (F-I) are chemically very active and can easily contaminate the food chain through their accumulation in the plants or aquatic systems. Heavy metals distributed in the carbonate bound (FII) and $\mathrm{MnO}_{2}$ bound (F-III) fractions are chemically less reactive but are easily transformed into the F-I fraction. However, the amorphous and crystalline $\mathrm{Fe}$ oxides bound (F-IV) as well as organically bound (FV) fractions are chemically very less reactive and are slowly transformed into the exchangeable or soluble fraction (F-I). On the other hand, heavy metals resides in the residual fraction (F-VI) are mostly unreactive and are not easily altered by environmental changes. These are also known as stable fraction.

Among the different fractions, a considerable portion of $\mathrm{Zn}$ were in the F-I ( $8.3 \%$ to $17.0 \%)$ and FII fractions ( $9.0 \%$ to $17.5 \%$ ) indicating its considerable mobility. However, a major portion of the total $\mathrm{Zn}$ appeared to be preferentially bound to fractions F-IV and F-V (41.0\% to $49.0 \%)$, which slowly transforms into the exchangeable or soluble fraction (F-I). The contents of $\mathrm{Cu}$ in the F-I, F-II and F-III fractions were low in all the sludge samples. Its content in the F-I was especially low (less than 5\%) (except for Bhatpara, Titagarh and Cossipore), indicating a less direct hazard to the environment. Major portion of total $\mathrm{Cu}$ is primarily associated with the organic matter content i.e., F-V. The highest extraction percentage of $\mathrm{Cu}$ was found in F-IV and F-V fractions for all the sludge samples. The F-IV and F-V fractions together accounted as high as $57 \%$ to $78 \%$ of total $\mathrm{Cu}$ in all the sludge samples, indicating its association with strong organic ligands and sesquioxide especially with Fe-oxide minerals.

Likewise $\mathrm{Cu}$, a very small portion of the $\mathrm{Pb}$ was distributed in F-I fraction $(<4.0 \%)$ in all the sludge samples, and it was especially low even at less than $2.0 \%$ in Titagarh, Howrah, Garden Reach and Chandannagar, indicating a less direct hazard to the environment. While a significant portion of the total $\mathrm{Pb}$ was distributed in F-II of Howrah (15.0\%), Srirampur (15.2\%), Cossipore (16.0\%) and Garden Reach (19.0\%), thus indicating its potential ecotoxicity. A considerable amount of the total $\mathrm{Pb}$ was also distributed in chemically very less reactive F-IV and F-V fractions. The fractions F-IV and F-V together accounted for more than $50.0 \%$ in all sludge samples (except for $44.0 \%$ in Howrah).

Among all the heavy metals under study, the fraction F-I was found highest for Cd; thereby indicating its highest mobility and bioavailability in all the sludge samples. Its quantity varied from $10.0 \%$ in Cossipore to $18.3 \%$ in Kamarhati and Howrah. The sum of fractions F-II and F-V (carbonate bound and organically bound fractions) ranged from $21.0 \%$ of the sludge Graden Reach to $43.0 \%$ of the sludge Bhatpara. A considerable portion of total Cd (above $30.0 \%$ ) was also distributed in the fraction F-VI (residual) of sludge Srirampur to Chandannagar, thus indicating its long-term stability in the environment.

Distribution of $\mathrm{Ni}$ in various fractions indicated a different pattern for all the sludge samples. Among the sludges, the fraction F-I was found to be higher in Graden Reach (10.0\%), Kamarhati \& Kalyani (11.0\%) and Chandannagar (13.0\%); while lower percentages of this fraction were found in Bhatpara $(4.3 \%)$, Titagarh and Srirampur (7.8\%). More than $30 \%$ of the total Ni was distributed in the fractions FII and F-IV together in most of the sludge samples viz., Bhatpara, Titagarh, Kamarhati, Kalyani, Cossipore and Graden Reach, showing potential bioavailability to the environment when soil conditions changed. 


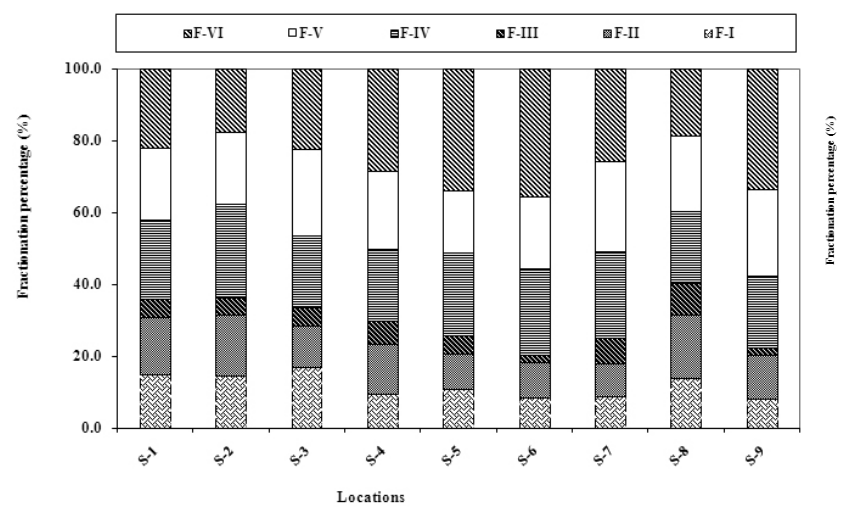

(A)

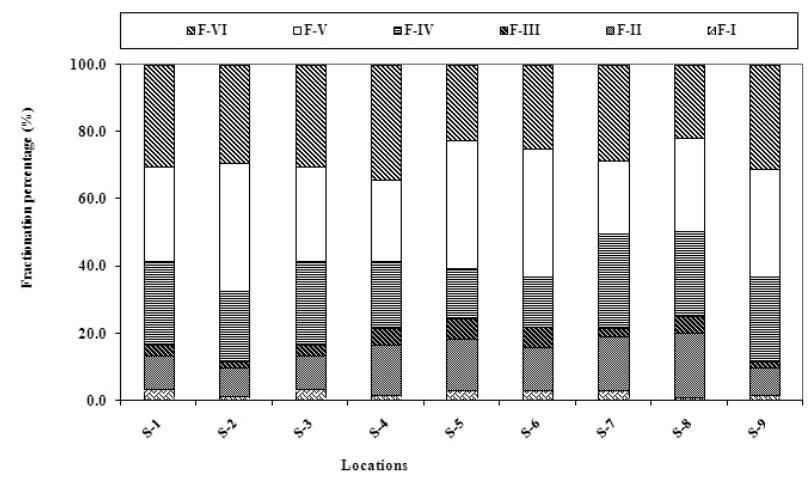

(C)

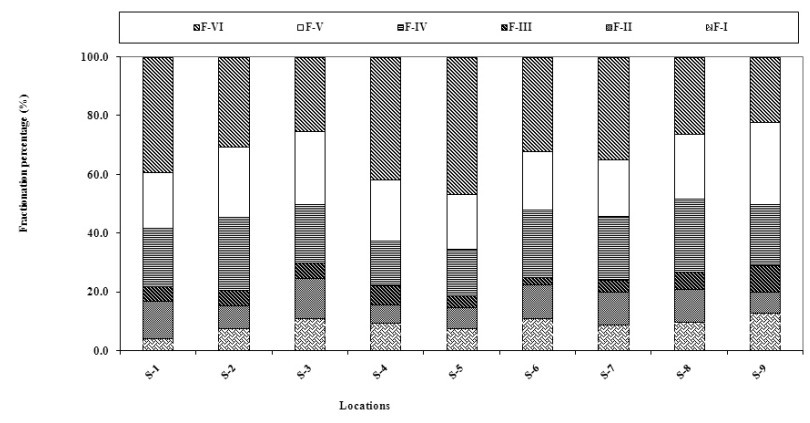

(E)

\section{Discussion}

Physico-chemical Characteristics and Mutrient Status of the Sludge

The sludge produced at different STPs of Kolkata was slightly acidic in reaction. Characterization of sewage sludge from India as well as from other countries clearly showed that $\mathrm{pH}$ of the sludge varies from slightly acidic to neutral range (Fanny et al., 2015; Nandakumar et al., 1998). The acidic nature of sludge may be ascribed to the decomposition of organic matter present in the sludge which may lower the $\mathrm{pH}$.

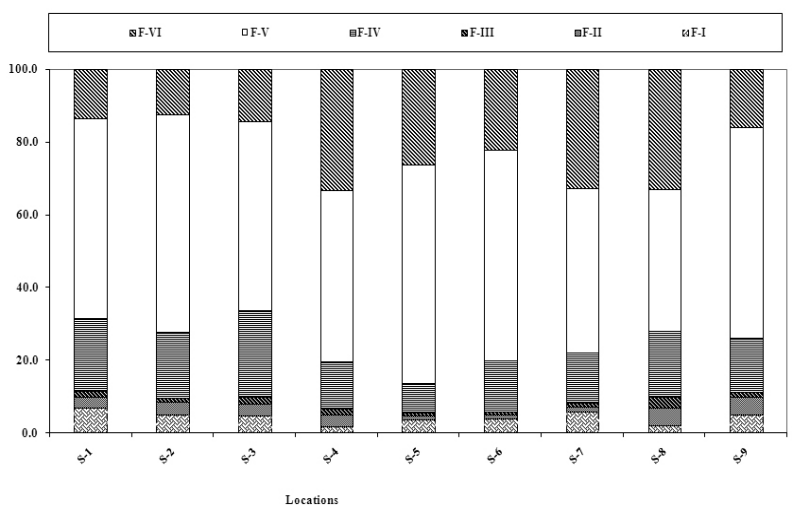

(B)

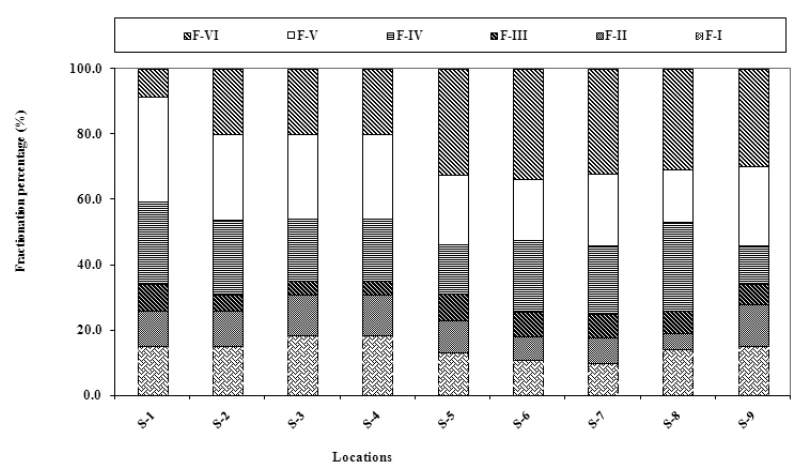

(D)

Fig. 2: Percentage of each fraction of heavy metals in sewage sludge of different locations extracted by sequential extraction procedure.

(F-I: Exchangeable; F-II: Carbonate bound; F-III: $\mathrm{MnO}_{2}$ bound; F-IV: Amorphous and crystalline Fe oxides bound; F-V: Organic matter bound; F-VI: Residual)

(A) $\mathrm{Zn}$; (B) $\mathrm{Cu}$; (C) $\mathrm{Pb}$; (D) $\mathrm{Cd}$; (E) $\mathrm{Ni}$

The sludge produced at different STPs in Kolkata was rich in major plant nutrients (mainly $\mathrm{N}$ and $\mathrm{P}$ ) and org. $\mathrm{C}$ content. As compared to $\mathrm{N}$ and $\mathrm{P}$, total $\mathrm{K}$ content was much lower in the sludge of Kolkata. The physico-chemical properties of the sludge collected from Tamil Nadu, India and Spain also showed that the sludge had very low content of total $\mathrm{K}$, as compared to the organic $\mathrm{C}, \mathrm{N}$ and $\mathrm{P}$ (Nandakumar et al., 1998). Our results are quite in accordance with the findings of Chitdeshwari et al. (2002), where they reported $6.70 \mathrm{pH}$ and $15.9 \% \mathrm{OC}$, as well as, available and total $\mathrm{N}, \mathrm{P}, \mathrm{K}$ content to the extent of 1230.0, 633.0, 380.0 $\mathrm{mg} \mathrm{kg}^{-1}$ and 3.62, 1.46, 
Table 4: Content of each heavy metal fractions in sludge samples of different locations

\begin{tabular}{|c|c|c|c|c|c|c|c|c|c|c|}
\hline \multirow[t]{2}{*}{ Element } & \multirow[t]{2}{*}{ Fraction } & \multicolumn{8}{|c|}{ Content of heavy metal $\left(\mathrm{mg} \mathrm{kg}^{-1}\right)$} & \multirow[b]{2}{*}{ S-9 } \\
\hline & & S-1 & $\mathrm{S}-2$ & S-3 & S-4 & S-5 & S-6 & S-7 & S-8 & \\
\hline \multirow[t]{6}{*}{$\mathrm{Zn}$} & F-I & $378.2 \pm 9.1$ & $374.8 \pm 7.5$ & $256.9 \pm 7.7$ & $154.1 \pm 5.6$ & $166.6 \pm 7.3$ & $111.8 \pm 5.1$ & $149.3 \pm 6.0$ & $283.0 \pm 5.7$ & $128.4 \pm 3.9$ \\
\hline & F-II & $403.4 \pm 7.5$ & $439.4 \pm 8.8$ & $176.8 \pm 5.3$ & $227.0 \pm 9.1$ & $145.4 \pm 7.3$ & $133.2 \pm 5.8$ & $149.3 \pm 5.4$ & $353.7 \pm 10.0$ & $185.6 \pm 7.4$ \\
\hline & F-III & $126.1 \pm 6.1$ & $129.2 \pm 2.6$ & $75.6 \pm 2.3$ & $102.2 \pm 3.7$ & $81.8 \pm 3.6$ & $26.6 \pm 1.2$ & $119.4 \pm 4.8$ & $181.9 \pm 3.6$ & $35.6 \pm 1.1$ \\
\hline & F-IV & $554.7 \pm 20.0$ & $672.0 \pm 13.4$ & $302.2 \pm 9.1$ & $324.3 \pm 13.0$ & $348.3 \pm 17.4$ & $319.7 \pm 13.9$ & $398.1 \pm 14.4$ & $404.3 \pm 18.5$ & $309.4 \pm 12.4$ \\
\hline & F-V & $504.3 \pm 9.3$ & $516.9 \pm 10.3$ & $362.7 \pm 10.9$ & $356.8 \pm 12.9$ & $262.0 \pm 11.4$ & $266.4 \pm 12.2$ & $414.7 \pm 16.6$ & $424.5 \pm 8.5$ & $371.2 \pm 11.1$ \\
\hline & F-VI & $554.7 \pm 20.0$ & $452.3 \pm 11.0$ & $337.0 \pm 10.1$ & $457.3 \pm 18.3$ & $510.3 \pm 11.0$ & $474.4 \pm 20.7$ & $428.0 \pm 15.4$ & $374.0 \pm 17.1$ & $516.6 \pm 20.7$ \\
\hline \multirow[t]{6}{*}{$\mathrm{Cu}$} & F-I & $9.56 \pm 0.60$ & $16.36 \pm 0.33$ & $16.43 \pm 0.49$ & $7.90 \pm 0.29$ & $13.23 \pm 0.58$ & $10.44 \pm 0.48$ & $22.55 \pm 0.90$ & $7.77 \pm 0.16$ & $14.44 \pm 0.43$ \\
\hline & F-II & $4.10 \pm 0.15$ & $11.45 \pm 0.23$ & $10.95 \pm 0.33$ & $15.13 \pm 0.61$ & $3.53 \pm 0.18$ & $2.61 \pm 0.11$ & $4.51 \pm 0.16$ & $19.43 \pm 0.89$ & $14.44 \pm 0.58$ \\
\hline & F-III & $2.19 \pm 0.14$ & $3.93 \pm 0.08$ & $6.16 \pm 0.18$ & $6.91 \pm 0.25$ & $3.32 \pm 0.14$ & $2.51 \pm 0.11$ & $3.76 \pm 0.15$ & $11.66 \pm 0.23$ & $3.47 \pm 0.10$ \\
\hline & F-IV & $27.32 \pm 0.99$ & $58.90 \pm 1.18$ & $82.13 \pm 2.46$ & $58.72 \pm 2.35$ & $28.22 \pm 1.41$ & $36.56 \pm 1.59$ & $52.61 \pm 1.90$ & $69.95 \pm 3.21$ & $43.32 \pm 1.73$ \\
\hline & $\mathrm{F}-\mathrm{V}$ & $75.13 \pm 5.00$ & $196.33 \pm 5.19$ & $177.95 \pm 6.61$ & $212.30 \pm 7.40$ & $211.68 \pm 3.69$ & $151.44 \pm 3.81$ & $169.11 \pm 7.36$ & $151.56 \pm 3.85$ & $167.50 \pm 4.20$ \\
\hline & F-VI & $18.30 \pm 2.38$ & $40.25 \pm 3.41$ & $48.60 \pm 4.67$ & $150.73 \pm 5.06$ & $92.82 \pm 3.29$ & $57.55 \pm 6.97$ & $123.26 \pm 5.25$ & $128.24 \pm 2.99$ & $45.63 \pm 3.12$ \\
\hline \multirow[t]{6}{*}{$\mathrm{Pb}$} & F-I & $13.61 \pm 0.85$ & $7.44 \pm 0.15$ & $15.58 \pm 0.47$ & $9.80 \pm 0.35$ & $17.71 \pm 0.77$ & $9.91 \pm 0.45$ & $13.30 \pm 0.53$ & $4.70 \pm 0.09$ & $9.05 \pm 0.27$ \\
\hline & F-II & $38.88 \pm 1.40$ & $49.81 \pm 1.00$ & $44.53 \pm 1.34$ & $91.28 \pm 3.65$ & $84.13 \pm 4.21$ & $39.94 \pm 1.74$ & $68.62 \pm 2.47$ & $81.13 \pm 3.72$ & $40.22 \pm 1.61$ \\
\hline & F-III & $12.44 \pm 0.78$ & $10.31 \pm 0.21$ & $14.25 \pm 0.43$ & $30.43 \pm 1.10$ & $33.21 \pm 1.45$ & $18.58 \pm 0.85$ & $10.72 \pm 0.43$ & $22.20 \pm 0.44$ & $10.06 \pm 0.30$ \\
\hline & F-IV & $97.20 \pm 3.50$ & $120.23 \pm 2.40$ & $111.32 \pm 3.34$ & $121.71 \pm 4.87$ & $83.03 \pm 4.15$ & $46.44 \pm 2.02$ & $120.09 \pm 4.33$ & $106.75 \pm 4.89$ & $125.70 \pm 5.03$ \\
\hline & $\mathrm{F}-\mathrm{V}$ & $108.7 \pm 6.80$ & $217.6 \pm 4.35$ & $124.7 \pm 3.74$ & $146.1 \pm 5.27$ & $210.3 \pm 9.17$ & $117.7 \pm 5.39$ & $94.4 \pm 3.77$ & $119.6 \pm 2.39$ & $160.9 \pm 4.83$ \\
\hline & F-VI & $117.8 \pm 4.25$ & $167.2 \pm 3.34$ & $134.9 \pm 4.05$ & $209.3 \pm 8.37$ & $125.1 \pm 6.25$ & $77.1 \pm 3.36$ & $121.8 \pm 4.39$ & $92.7 \pm 4.25$ & $156.9 \pm 6.27$ \\
\hline \multirow[t]{6}{*}{$\mathrm{Cd}$} & F-I & $0.89 \pm 0.06$ & $0.86 \pm 0.02$ & $0.59 \pm 0.02$ & $1.24 \pm 0.04$ & $1.31 \pm 0.06$ & $0.51 \pm 0.02$ & $0.62 \pm 0.02$ & $0.46 \pm 0.01$ & $0.79 \pm 0.02$ \\
\hline & F-II & $0.66 \pm 0.02$ & $0.60 \pm 0.01$ & $0.40 \pm 0.01$ & $0.85 \pm 0.03$ & $1.01 \pm 0.05$ & $0.34 \pm 0.01$ & $0.49 \pm 0.02$ & $0.16 \pm 0.01$ & $0.69 \pm 0.03$ \\
\hline & F-III & $0.49 \pm 0.03$ & $0.28 \pm 0.01$ & $0.14 \pm 0.04$ & $0.30 \pm 0.01$ & $0.84 \pm 0.04$ & $0.35 \pm 0.02$ & $0.44 \pm 0.02$ & $0.23 \pm 0.05$ & $0.32 \pm 0.01$ \\
\hline & F-IV & $1.49 \pm 0.05$ & $1.30 \pm 0.03$ & $0.60 \pm 0.02$ & $1.27 \pm 0.05$ & $1.51 \pm 0.08$ & $1.02 \pm 0.04$ & $1.31 \pm 0.05$ & $0.89 \pm 0.04$ & $0.63 \pm 0.03$ \\
\hline & $\mathrm{F}-\mathrm{V}$ & $1.91 \pm 0.06$ & $1.47 \pm 0.03$ & $0.84 \pm 0.03$ & $1.77 \pm 0.06$ & $2.12 \pm 0.09$ & $0.87 \pm 0.04$ & $1.37 \pm 0.05$ & $0.52 \pm 0.01$ & $1.27 \pm 0.04$ \\
\hline & F-VI & $0.52 \pm 0.02$ & $1.14 \pm 0.02$ & $0.65 \pm 0.02$ & $1.37 \pm 0.05$ & $3.30 \pm 0.16$ & $1.58 \pm 0.07$ & $2.01 \pm 0.07$ & $1.02 \pm 0.05$ & $1.58 \pm 0.06$ \\
\hline \multirow[t]{6}{*}{$\mathrm{Ni}$} & F-I & $5.40 \pm 0.34$ & $10.07 \pm 0.20$ & $23.66 \pm 0.71$ & $21.24 \pm 0.77$ & $15.48 \pm 0.67$ & $42.74 \pm 1.96$ & $21.20 \pm 0.85$ & $32.16 \pm 0.64$ & $24.52 \pm 0.74$ \\
\hline & F-II & $15.81 \pm 0.57$ & $10.07 \pm 0.20$ & $29.47 \pm 0.88$ & $14.16 \pm 0.57$ & $13.70 \pm 0.68$ & $45.45 \pm 1.98$ & $25.91 \pm 0.93$ & $35.37 \pm 1.62$ & $13.20 \pm 0.53$ \\
\hline & F-III & $6.28 \pm 0.39$ & $6.46 \pm 0.13$ & $11.40 \pm 0.34$ & $14.38 \pm 0.52$ & $8.54 \pm 0.37$ & $9.32 \pm 0.43$ & $9.42 \pm 0.38$ & $18.65 \pm 0.37$ & $16.97 \pm 0.51$ \\
\hline & F-IV & $25.10 \pm 0.90$ & $32.28 \pm 0.65$ & $43.03 \pm 1.29$ & $34.84 \pm 1.39$ & $30.97 \pm 1.55$ & $89.36 \pm 3.89$ & $51.82 \pm 1.87$ & $80.40 \pm 3.68$ & $39.60 \pm 1.58$ \\
\hline & $\mathrm{F}-\mathrm{V}$ & $23.85 \pm 1.49$ & $30.98 \pm 0.62$ & $53.57 \pm 1.61$ & $46.07 \pm 1.66$ & $37.12 \pm 1.62$ & $77.31 \pm 3.54$ & $44.76 \pm 1.79$ & $70.75 \pm 1.41$ & $52.81 \pm 1.58$ \\
\hline & F-VI & $49.07 \pm 1.77$ & $39.25 \pm 0.78$ & $54.00 \pm 1.62$ & $94.06 \pm 3.76$ & $92.70 \pm 4.63$ & $124.32 \pm 5.42$ & $82.45 \pm 2.97$ & $84.25 \pm 3.86$ & $41.49 \pm 1.66$ \\
\hline
\end{tabular}


$2.53 \%$, respectively, of sewage biosolid from sewage farm of Ukkadam, Coimbatore. Results also indicated that the concentrations of total $\mathrm{N}, \mathrm{P}$ and $\mathrm{K}$ content in the sludges originating from different locations of Kolkata were higher than those produced in different cities of India viz., Ahmedabad, Jaipur, Delhi, Nagpur, Chennai and Jaipur, where the magnitude of total N, $\mathrm{P}$ and $\mathrm{K}$ contents were in the range of $0.82-2.34$, 0.51-0.94 and 0.11-0.23\% respectively (Juwarkar et al., 1991). However, total N, P and K content in sludge produced in different STPs of Kolkata under study were several times higher than those previously reported by Maiti et al. (1992) in sludge collected from Kolkata (0.34-0.56, 0.11-0.12 and 0.36-0.59\% for $\mathrm{N}, \mathrm{P}$ and $\mathrm{K}$, respectively). The concentrations of different nutrients in sludge produced from waste water treatment plant of Guangzhou, China ranged from 28.1 to $60.6 \%$ for organic C, 1.25 to $3.83 \%$ for total N, 1.19 to $3.62 \%$ for total $\mathrm{P}$, and 0.67 to $1.91 \%$ for total K were also reported by Liu and Sun (2013).

\section{Heavy Metals Concentration}

The differences in the concentrations of heavy metals also corroborated with the findings of Liu and Sun (2013), where they reported higher concentration of $\mathrm{Cu}$ and $\mathrm{Zn}$ but relatively lower concentrations of $\mathrm{Cr}$, $\mathrm{Ni}$ and $\mathrm{Pb}$ in sewage sludge from Guangzhou province of China. Sewage sludge collected from Tamil Nadu, India also showed relatively higher concentration of $\mathrm{Cu}$ and $\mathrm{Zn}$ (700.00 and $1900.0 \mathrm{mg} \mathrm{kg}^{-1}$, respectively) but very low concentration of $\mathrm{Cd}\left(1.00 \mathrm{mg} \mathrm{kg}^{-1}\right)$ (Nandakumar et al., 1998). However, the present findings were several folds lower than the total concentrations of $\mathrm{Zn}, \mathrm{Cu}, \mathrm{Pb}, \mathrm{Cd}$ and $\mathrm{Ni}$ (i.e. 2630.0, $2680.0,5720.0,923.0$ and $3460.0 \mathrm{mg} \mathrm{kg}^{-1}$, respectively) in sludge samples collected from sewage farm of Ukkadam, Coimbatore, India as reported by Chitdeshwari et al. (2002). The exhibition of spatial variations in concentrations of heavy metals in sewage sludge may be ascribed to the variations in their sources (industrial, domestic or mixture of both) and quantity of heavy metals discharged through the effluents and sewage for treatment through the STPs (Saha et al., 2015).

The sludge collected from a sewage plant at Changsha in Hunan Province of China also contained $\mathrm{Cu}, \mathrm{Zn}, \mathrm{Pb}, \mathrm{Cd}$ and $\mathrm{Ni}$ to the tune of 518.0, 1195.0, $120.8,5.5$ and $82.5 \mathrm{mg} \mathrm{kg}^{-1}$ dried sludge, respectively
(Yuan et al., 2011). Singh and Agrawal (2010) also reported that the sewage sludge collected from Dinapur STP of Varanasi, India contained $785.3 \mathrm{mg}$ $\mathrm{kg}^{-1} \mathrm{Zn}, 317.7 \mathrm{mg} \mathrm{kg}^{-1} \mathrm{Cu}, 60.0 \mathrm{mg} \mathrm{kg}^{-1} \mathrm{~Pb}, 154.5$ $\mathrm{mg} \mathrm{kg}{ }^{-1} \mathrm{Cd}$ and $47.17 \mathrm{mg} \mathrm{kg}^{-1} \mathrm{Ni}$.

The variation in concentration of heavy metals amongst different locations may possibly be ascribed to the large variation in quantity as well as quality of the raw sewage each of the STP receives for its treatment. This finding further indicated that sewage effluent discharged by certain industries does not meet the specified standards. As a consequence, these toxic metals get settled and are accumulated in the sludge, which ultimately results in high heavy metals content in the sludge (Liu and Sun, 2013).

The sludges produced at different STPs in Kolkata should not be applied directly in soil for growing agricultural crops unless certain remediation measures viz., phytoremediation or chemical remediation steps are taken to check the transfer of toxic heavy metals in to the food chain. For the phytoremediation of heavy metals, some materials known as mobilizing agents viz. EDTA, organic acids etc. are also available that mobilize the heavy metals in soil and the released concentration then can be hyper-accumulated by plants, thus reducing the level of heavy metal in soil. On the other hand, chemical remediation involves use of some reactive materials that are available in large quantities and certain waste products from industrial or agricultural operations viz. basic slag, lime, rock phosphate, fly ash, rice husk char etc. may have a potential as inexpensive amendments for heavy metal immobilization in the soil.

Comparing the concentrations of heavy metals in sludges of Kolkata with the maximum permissible limits as followed in USA and Canada indicated that concentrations of metals (except for Pb in USA and $\mathrm{Pb} \& \mathrm{Ni}$ in Canada) does not exceed the maximum permissible values for their use in agriculture. However, compared to the permissible values as suggested by European Communities, the concentration of all the heavy metals in sludges were quite less than the maximum limits (except for $\mathrm{Zn}$ in locations Bhatpara and Titagarh) and the sludge from these sites therefore can be used safely in agriculture. 


\section{Heavy Metals Speciation}

Zinc, in sewage sludge originated from different STPs in Kolkata has a high bioavailability and potential ecotoxicity to the environment. The present findings corroborated with the previous study of Liu and Sun (2013), where they also reported considerable portion of $\mathrm{Zn}$ in sludge samples were in the exchangeable and carbonate bound fractions indicating its greatest degree of mobility.

The highest extraction percentage of $\mathrm{Cu}$ was found in F-IV and F-V fractions for all the sludge samples, which is due to the affinity of organic matter and Fe-oxides minerals with the $\mathrm{Cu}$ and the formation of stable complexes (Farrel et al., 2010; Liu and Sun, 2013). It has also been reported by Zaleckas et al. (2013), that approximately $50.0 \%$ of the total $\mathrm{Cu}$ content was associated with the organically bound fraction in the sewage sludge from Kaunas, Lithuania. As these fractions are very slowly transformed into more chemically reactive exchangeable and soluble fractions, the $\mathrm{Cu}$ in all the sludge samples has a high potential for ecotoxicity and bioavailability to the soil, when treated with these sludges.

As the fractions F-IV and F-V (amorphous and crystalline Fe oxides bound and organically bound, respectively) constituted a significant portion of the total content, therefore, $\mathrm{Pb}$ in sewage sludge has potential bioavailabilty and ecotoxicity as long term changes related to the soil acidity or intensive organic matter mineralization can lead to increased mobility of the element (Zaleckas et al., 2013). The strong affinity of organic matter with the $\mathrm{Pb}$ in reducing its bioavailability has also been reported by Farrel and Jones (2010) and Farrel et al. (2010). However, more than $30 \%$ of the total $\mathrm{Pb}$ was present in the fraction F-VI of Bhatpara, Kamarhati and Howrah, thus indicating its low direct and potential bioavailability to the environment if applied as soil conditioners or organic fertilizers. $\mathrm{Pb}$ was predominantly distributed in the carbonate bound and residual fractions, and were also reported by Zaleckas et al. (2013).

High bioavailability of $\mathrm{Cd}$ to the environment on changes of soil conditions has also been reported by Liu and Sun (2013). The sequential extraction procedure also clearly indicated that a significant portion of $\mathrm{Cd}$ in sludge samples $(\sim 24.0 \%$ on an average) are distributed in the exchangeable and carbonate bound fraction, which was further confirmed by Zaleckas et al. (2013).

Our results are in good agreement with the other earlier studies viz. Fuentes et al. (2004); Liu and Sun (2013), where they reported high mobility of $\mathrm{Ni}$ in the fractionation of heavy metal in different sludge samples. However, among all the metals under study, a greater percentage of total $\mathrm{Ni}$ was found in the chemically unreactive F-VI fraction, indicating its long-term stability and thus lower risk to the environment. Its quantities ranged from $22.0 \%$ in Chandannagar to $46.7 \%$ in Srirampur.

The distribution of heavy metals into their different chemical fractions does not follow the same trend for all the sludge samples. Among the metals, chemically very active fraction (F-I) was found to be relatively higher for Zn (except in Howrah, Kalyani, Cossipore and Chandannagar), $\mathrm{Cd}$ and $\mathrm{Ni}$ (except in Bhatpara, Titagarh, Srirampur and Cossipore). Except for $\mathrm{Cu}$, the carbonate bound fraction (F-II) in different sludge samples was relatively higher for all the metals viz. $\mathrm{Zn}$ (except in Srirampur and Cossipore), $\mathrm{Pb}$ (except in Titagarh and Chandannagar), Cd (except in Kalyani, Cossiporeand Graden Reach) and Ni (except in Titagarh, Howrah, Srirampur and Chandannagar). With the exception of $\mathrm{Cu}$, other heavy metals viz. $\mathrm{Zn}, \mathrm{Pb}, \mathrm{Cd}$ and $\mathrm{Ni}$ had a higher percentage (on an average over 20.0\%) in the amorphous and crystalline Fe oxides bound fraction (F-IV). On the other hand, the organically bound fraction $(\mathrm{F}-\mathrm{V})$, on an average, was found to be highest for $\mathrm{Cu}$ (over $50.0 \%)$ followed by $\mathrm{Pb}(30.7 \%), \mathrm{Cd}(23.5 \%)$, Ni $(21.8 \%)$ and $\mathrm{Zn}(21.5 \%)$.

It was further revealed that in the sludge samples from Bhatpara, Titagarh and Kamarhati, both the heavy metals i.e., $\mathrm{Zn}$ and $\mathrm{Cd}$ had a higher percentage (over $25.0 \%$ ) in the chemically very active fractions (F-I and F-II together), while in the sample from Garden Reach, Zn alone had a higher percentage of these fractions. On the other hand, $\mathrm{Cd}$ had a larger percentage of these active fractions in the samples from Howrah and Chandannagar. The results, therefore, indicated that the samples from Bhatpara, Titagarh, Kamarhati, Howrah, Graden Reach and Chandannagar have significantly higher mobility and bioavailability of either of the $\mathrm{Zn}$ and $\mathrm{Cd}$ or both, than those in other samples. Since the mass percentage of heavy metals in first two fractions are characterized 
as highly mobile and easily bioavailable (Zaleckas et al., 2013), the heavy metals can be ranked in the following order according to their possibility to cause toxic hazards to living organisms in the environment:

$$
\mathrm{Zn}>\mathrm{Cd}>\mathrm{Ni}>\mathrm{Pb}>\mathrm{Cu}
$$

The fraction F-VI (residual fraction) can be characterized as absolutely immobile because this fraction represented that portion of the metal mass which is bound to insoluble, stable and poorly degradable compounds (Zaleckas et al., 2013), therefore, according to their long-term stability in the environment, the heavy metals can be categorized as follows:

$$
\mathrm{Ni}>\mathrm{Pb}>\mathrm{Zn}>\mathrm{Cd}>\mathrm{Cu}
$$

\section{Conclusions}

Sewage sludge produced in different STPs of Kolkata was rich in org. $\mathrm{C}$ and major plant nutrients mainly, $\mathrm{N}$ and $\mathrm{P}$ but low in $\mathrm{K}$.

The concentrations of $\mathrm{Zn}, \mathrm{Pb}$ and $\mathrm{Ni}$ in all the sludges exceeded the permissible levels as recommended by Central Pollution Control Board (CPCB) for use of municipal solid waste in agriculture. The concentrations of $\mathrm{Cu}$ (except for Bhatpara and Chandannagar) and $\mathrm{Cd}$ (except for Kamarhati and Graden Reach) in all the locations exceeded the permissible levels, therefore it should be restricted for agricultural use. The results therefore suggest that the sludges produced at different STPs

\section{References}

Antonious G F (2009) Enzyme activities and heavy metals concentration in soil amended with sewage sludge $J$ Environ Sci Health, Part A 44 1019-1024

APHA (1995) Standards methods for the examination of water and wastewater. American Public Health Association, 19th ed. Water Pollution Control Federation, New York, USA

Balkhair K S and Ashraf M A (2016) Field accumulation risks of heavy metals in soil and vegetable crop irrigated with sewage water in western region of Saudi Arabia Saudi J Biol Sci 23 32-44

Chitdeshwari T, Savithri S and Raja M (2002) Effect of sewage biosolids compost on biomass yield of amaranthus and heavy metal availability J Indian Soc Soil Sci 50 481-484 in Kolkata should not be used directly for agricultural purposes unless subjected to phytoremediation or chemical remediation of the sludge treated soils for reducing heavy metals loads in the harvested sink.

Speciation study suggests that except some samples, a considerable portion of $\mathrm{Zn}, \mathrm{Cd}, \mathrm{Pb}$ and $\mathrm{Ni}$ were distributed in the fractions F-I, F-II and F-IV, indicating high bioavailability and potential ecotoxicity to the environment. While the $\mathrm{Cu}$ was primarily distributed in the organically bound fraction F-V. The results further indicated that the sludges produced at Bhatpara, Titagarh, Kamarhati, Howrah, Graden Reach and Chandannagar have significantly higher mobility and bioavailability of either of the $\mathrm{Zn}$ and $\mathrm{Cd}$ or both than those in the other samples.

While evaluating relative metal mobility and stability in environment according to the fractions F$\mathrm{I}$ and F-II together and F-VI in the sludge samples, the ranking follows the order of: $\mathrm{Zn}>\mathrm{Cd}>\mathrm{Ni}>\mathrm{Pb}>$ $\mathrm{Cu}$ (relative mobility) and $\mathrm{Ni}>\mathrm{Pb}>\mathrm{Zn}>\mathrm{Cd}>\mathrm{Cu}$ (relative stability).

\section{Acknowledgements}

The authors wish to acknowledge the financial assistance of All India Co-ordinated Research Project on "Micro- and Secondary Nutrients and Pollutant Elements in Soils and Plants" funded by Indian Council of Agricultural Research, Govt. of India for carrying out this research.

CPCB (2006) Characterization of MSW compost and its application in agriculture. Central Pollution Control Board, New Delhi

Dubey S K, Yadav R K, Joshi P K, Chaturvedi R K, Goyel B, Yadav R and Minhas P S (2006) Agricultural uses of sewage sludge and water and their impact on soil water and environmental health in Haryana, India. Proceedings of the $18^{\text {th }}$ World Congress of Soil Science, July 9-15, Philadelphia, Pennsylvania, USA pp 81-82, International Union of Soil Sciences, Soil Science Society of America and National Academy of Sciences (U.S.)

Fanny S R, Jorge M E, Mario U M and Cruz M Q (2015) Degradation of sewage sludge from plant wastewater using vermicompost Int J Modern Biol Res 4 1-4

Farmer A M (2012) Manual of European Environmental Policy. 
Routledge, London

Farrell M and Jones D L (2010) Use of composts in the remediation of heavy metal contaminated soil $J$ Hazard Mater 175 575-582

Farrell M, Perkins W T, Hobbs P J, Griffith G W and Jones D L (2010) Migration of heavy metals in soil as influenced by compost amendments Environ Pollut 158 55-64

Fuentes A, Liorens M, Sáez J, Soler A, Aguilar M I, Ortuño J F and Meseguer V F (2004) Simple and sequential extractions of heavy metals from different sewage sludges Chemosphere 54 1039-1047

Hooda P S and Alloway B J (1994) Changes in operational fractions of trace metals in two soils during two-years of reaction time following sewage sludge treatment Int $J$ Environ Anal Chem 57 289-311

Jackson M L (1973) Soil chemical analysis.Prentice Hall India, New Delhi

Juwarkar A S, Juwarkar A, Desbhratar P B and Bal A S (1991) Exploitation of nutrient potential of sewage and sludge through land application. In: Asian experience in integrated plant nutrition, Regional office for Asia and Pacific (RAPA) pp 178-201, Food and Agriculture Organization of the United Nations, Bangkok

Kaur R, Wani S P, Singh A K and Lal K (2012) Wastewater production, treatment and use in India. National report presented at the $2^{\text {nd }}$ regional workshop on safe use of wastewater in agriculture, May 16-18, 2012, New Delhi, India. http://www.ais.unwater.org/ais/pluginfile.php/356/ mod_page/content/111/CountryReport_India.pdf. Accessed 04 July 2017

Liu J and Sun S (2013) Total concentrations and different fractions of heavy metals in sewage sludge from Guangzhou, China Trans Nonferrous Met Soc China 23 2397-2407

Ma X, Weng H and Zhang J (2011) Regional characteristics and trend of heavy metals and nutrients of sewage sludges in China China Environ Sci 31 1306-1313

Maiti P S, Sah K D, Gupta S K and Banerjee S K (1992) Evaluation of sewage sludge as a source of irrigation and manure $J$ Indian Soc Soil Sci 40168-172

Meng W, Wang Z, Hu B, Wang Z, Li H and Goodman R C (2016) Heavy metals in soil and plants after long-term sewage irrigation at Tianjin China: A case study assessment Agric Water Manag 171 153-161

Nandakumar K, Ramamurthy S, Rajarajan A and Savarimuthu E (1998) Suitability of Dindigul town's sewage sludge for field application: Nutritional perspective Poll Res 17 6163
Nelson D W and Sommers L E (1982) Total carbon, organic carbon, and organic matter. In: Methods of soil analysis, Part 2, 2nd edn. (Eds: Page A L, Miller R H and Keeney D R) pp 539-579, Agronomy Monograph, 9, ASA and SSSA, Madison, Wisconsin

Outhman A M and Firdous F (2016) The impact of the use of sludge in agriculture on the vegetative growth of cereal crops Int J Adv Industrial Eng 4 1-9

Page A L, Miller R H and Keeney D R (1982) Methods of Soil Analysis, Part-2, 2nd edn. American Society of Agronomy and Soil Science Societyof America, Madison, Wisconsin

Placek A, Grobelak A and Kacprzak M (2016) Improving the phytoremediation of heavy metals contaminated soil by use of sewage sludge Int J Phytoremediation 18 605-618

Richard L A (1954) Diagnosis and improvement of saline and alkaline soils. Handbook No. 60, U.S. Salinity Laboratory Staff, U.S. Dept. of Agriculture, Washington D.C

Saha S, Hazra G C, Saha B N and Mandal B (2015) Assessment of heavy metals contamination in different crops grown in long-term sewage-irrigated areas of Kolkata, West Bengal, India Environ Monit Assess 187 1-9 (Article ID 4087)

Saha S, Saha B N, Pati S, Pal B and Hazra G C (2017) Agricultural use of sewage sludge in India: benefits and potential risk of heavy metals contamination and possible remediation options - A review Int J Environ Tech Manag 20 183-199

Silva J G D, de Carvalho J J, da Luz J M R and da Silva J E C (2016) Fertigation with domestic wastewater: uses and implications Afr J Biotechnol 15 806-815

Singh R P and Agrawal M (2010a) Variations in heavy metal accumulation, growth and yield of rice plants grown at different sewage sludge amendment rates Ecotoxicol Environ Saf 73 632-641

Tessier A, Campbell P G C and Bisson M (1979) Sequential extraction procedure for the speciation of particular trace metals Anal Chem 51 844-850

Yuan X, Huang H, Zeng G, Li H, Wang J, Zhou C, Zhu H, Pei X, Liu Z an Liu Z (2011) Total concentrations and chemical speciation of heavy metals in liquefaction residues of sewage sludge Bioresour Technol 102 4104-4110

Zaleckas E, Paulauskas V and Sendpikienë E (2013) Fractionation of heavy metals in sewage sludge and their removal using low-molecular-weight organic acids J Environ Eng Landsc Manage 21 189-198. 